\title{
Sedimentary cover in former South-East Lithuania glaciolacustrine basin and its influence for groundwater infiltration
}

\author{
Algimantas Česnulevičius ${ }^{\mathrm{a}, \mathrm{b}}$ \\ ${ }^{a}$ Department of Hydraulics, Vilnius Gediminas Technical University, Sauletekio ave. 11, Vilnius 10223, Lithuania \\ ${ }^{b}$ Cartographic Center, Vilnius University, M. K.Čiurlionio str. 21/27, Vilnius 03101, Lithuania
}

\begin{abstract}
The emergence of periglacial lakes in the territory of Lithuanian was conditioned by recessions and oscillations of the Baltija stage of Nemunas glacial. The slow recession of the glacier edge affected the evolution and drainage of the basins. Establishment of the drainage levels and analysis of the sections of glaciolacustrine sediments allows revealing their relationships with the recession phases of degrading glacier. The last stage of East and South Lithuanian glaciolacustrine basins - full drainage - was very important in their evolution. The intensity of glaciolacustrine drainage could be slow or cataclysmic. At one time in Late Glacial (Weichselian) existed seven large glaciolacustrin bassins. The oldest (about $130 \mathrm{ka}$ ) occupied glaciodepresions between Neris Middlestream, Vilnia and Dainava icetongues. Small and shallow basins were in high level: the eastern basin which affluent by Neris Middlestream and Vilnia ice-tongues shoreline was fixed in $220 \mathrm{~m}$ (Ašmena, in Belarus) and western basin which affluent by Vilnia and Dainava ice-tongues - in $200 \mathrm{~m}$ about middle sea level (ASL). In next stage (17-19 ka) cascade of glaciolacustrin basin existed in East Lithuania. The highest level basins had in north part and lowest - in south: Žeimena glaciolacustrine basin was in 155-160 m ASL, the Labanoras - 150-155, the Vilnia - 140-145 m, the Merkys Middlestream - 135 m, the Dubičiai - 125, the Biebrza (in Poland) - 110 m ASL. In central parts of former glaciolacustrine basins accumulated clay and loam, in peripherial parts - gravel, sand and silt. The granulometric composition of sediment layers determined infiltration conditions of recent surface-water. The goal of this article - evaluate infiltration condition and amount of surface-water in central and peripheral parts of different former glaciolacustrine basins.
\end{abstract}

Keywords: groundwater; infiltration; surface-water; sediments; glaciolacustrine.

\section{Introduction}

For structural analysis of the littoral sediments of glaciolacustrine basins samples were taken from the quarry outcrops and ad hoc excavations. The granulometric composition of sediment layers was determined by screening of sediment samples were taken in the quarry outcrops and excavations situated in the eastern and western littoral parts of glaciolacustrine basins and in the basin bottoms.

At one time in Late Glacial (Weichselian) existed seven large glaciolacustrin basins (Fig. 1). The oldest existed in Brandenburg Stage. It's occupied glaciodepresions between Neris Middlestream, Vilnia and Dainava ice-tongues. Small and

shallow basins were in high level: the eastern basin which affluent by Neris Middlestream and Vilnia ice-tongues shoreline was fixed in $220 \mathrm{~m}$ and western basin which affluent by Vilnia and Dainava ice-tongues - in $200 \mathrm{~m}$ about sea level (ASL) (Fig. 2).

In Frankfurt Stage cascade of glaciolacustrin basin existed in East Lithuania. The highest level basins had in north part and lowest - in south. The Žeimena glaciolacustrine basin was in 155-160 m ASL, the Labanoras - 150-155, the Vilnia - 140-145 $\mathrm{m}$, the Merkys Middlestream - $135 \mathrm{~m}$. The shoreline altitudes coherently sink from north-east to south-west (Fig. 3). The lowest Dubičiai basin was in contemporary Lithuania - Belarus border. In south-east Lithuania extant some north shoreline terraces, which was in 135, 130, 125 and $120 \mathrm{~m}$ ASL and south former glaciolacustrin shoreline are fixed in Biebrza River basin, North-East Ploland.

Corresponding author: Algimantas Česnulevičius. E-mail address: algimantas.cesnulevicius@gf.vu.lt

http://dx.doi.org/10.3846/enviro.2014.073

(C) 2014 The Authors. Published by VGTU Press. This is an open-access article distributed under the terms of the Creative Commons Attribution License, which permits unrestricted use, distribution, and reproduction in any medium, provided the original author and source are credited. 


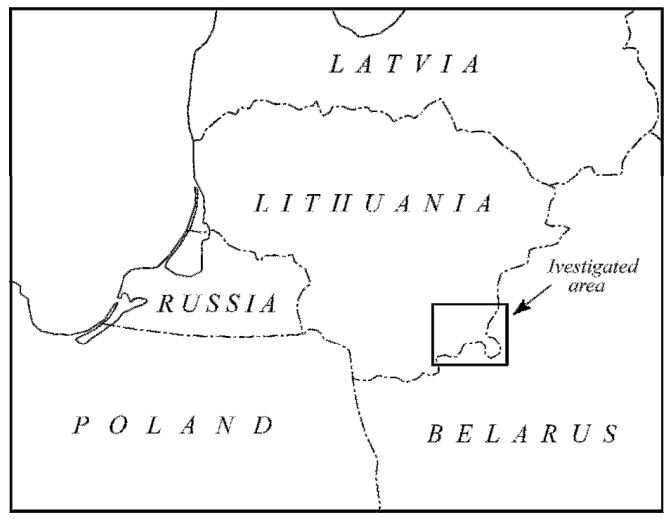

Fig. 1. Investigated area

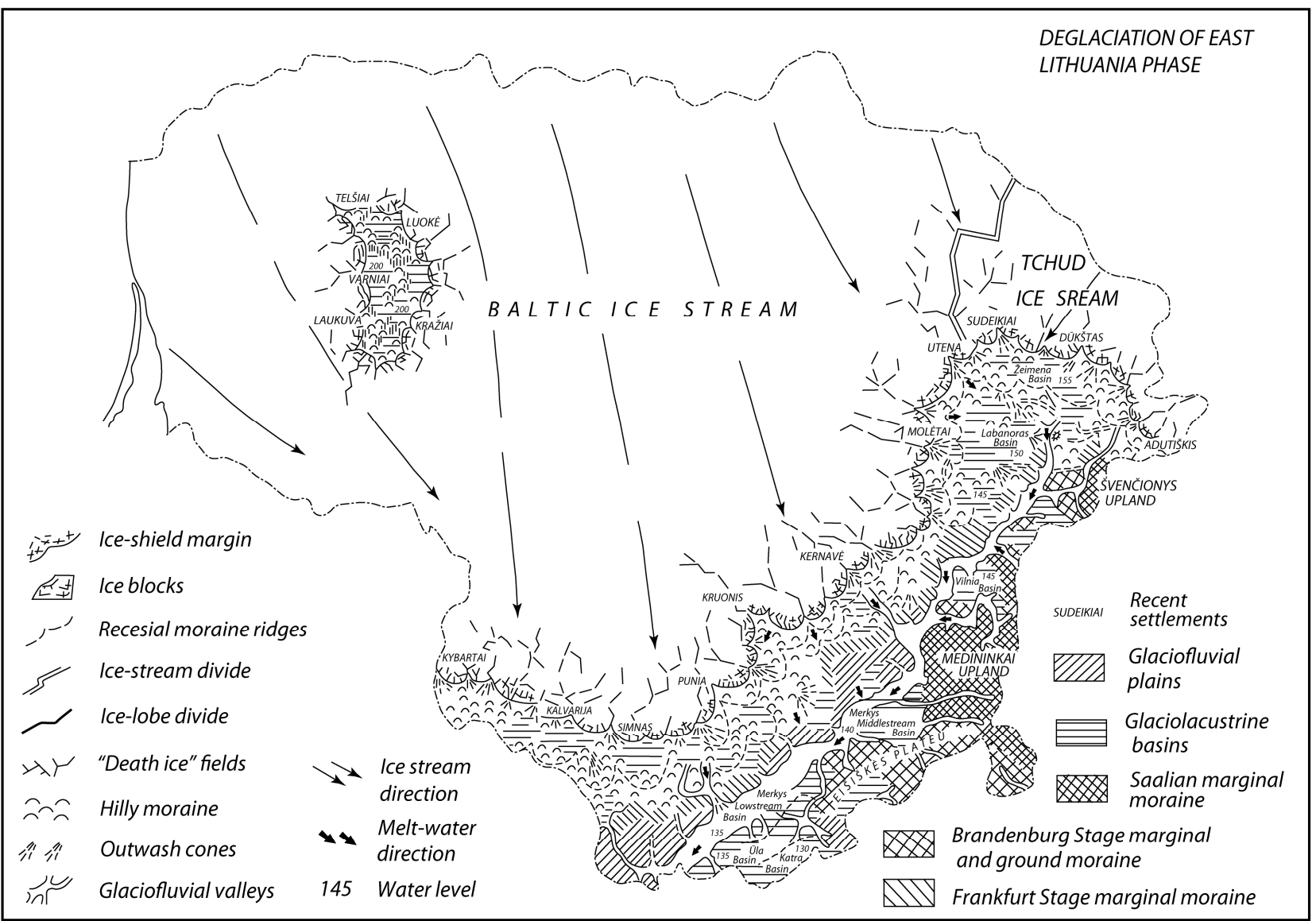

Fig. 2. Ice - sheet deglaciation during East Lithuania Phase

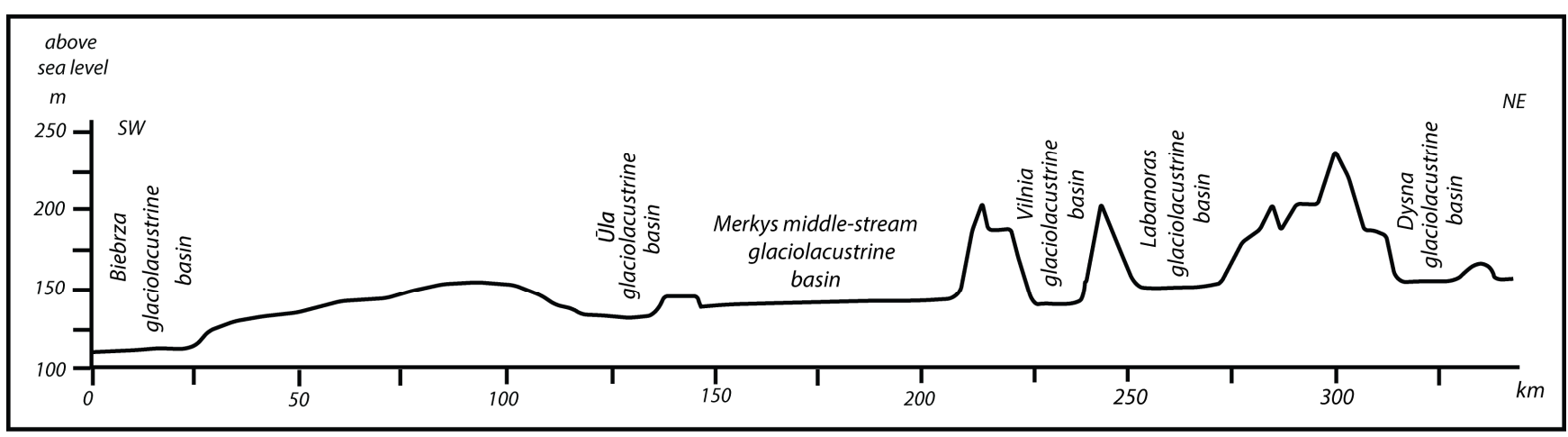


Fig. 3. Cross-section from North- East to South - West Lithuania

Depths of the last ice-age glaciolacustrine basins were quite different. This fact resulted sediments sedimentation in them. In deep glaciolacustrine basins the fine-grained sediments have been developing (like clay or silt) distinguishing with a very bad infiltration conduction. In shallow glaciolacustrine basins the various-grained sands have been covering. Their infiltration conduction is significantly better. The variety of sediments results nowadays precipitation and snow melting water infiltration and subterranean water resources.

\section{Methods}

For determining the arrangement of the shores of the former glaciolacustrine basins and distribution of terraces, large-scale topographic maps and aerophotographs were used. Relief forms were investigated by the cartographic, descriptive and granulometric analysis of sediments [1], [2]. It enabled to define relief evolution in the South-East Lithuania glaciolacustrine basins zone by permafrost, erosion, eolian, fluvial and organogenic formations [3]. Two different shoreline type zones are determined in investigation area: upper eastern and lower western. In eastern part dominated periglacial erosion, which embody by gullies, ravines, meltwater valleys. In western part predominated gullies and ravines, which joined in complicated network thermokarst holes and kettles. Relief form analysis basis on distinguishing different genesis, age and morphometric parameters of surface rough. For this aim was used geological, geomorphological, sediments land using thematic maps and data basis.

More effective are large-scale topographic maps for relief decompose, because the important reason, which evidence to glaciolacustrine basin existence are old gullies network. The gullies which mouth opened in glaciolacustrin basins have complicate structure: multi-arms, volatile longitudinal section. Long time of existence decided different possibilities in gullies evolution: when basins water level sink, the longitudinal section of gullies followed them. The mouths part of gullies in time become in convex form.

All these complicated after-glacier processes have formed quite varied surface sediments covers, resulting previous glaciolacustrine basin bottom infiltration qualities.

For evaluation of groundwater balance in former glaciolacustrine basins was used integrated methods [4].

\section{Results}

The sediments changes illustrated evolution of glaciolacustrine basins. In old shoreline levels (135, 130,125 and $120 \mathrm{~m}$ ASL.) are fine-grained and coarse-grained sediments layers. Coarse-grained layers are thin and oblique, it show that stable shorelines level was exist only short time.

The glaciolacustrine basins were stretched among two uplands belt: Saalian Ašmena Upland in east and Weichselian marginal Baltic Uplands in west. Distance between it uplands are only $10-60 \mathrm{~km}$ and this fact had essential importance for evolution all urström.

The Medininkai Upland and Eišiškès Plateau are in a periglacial zone of the Last Glaciation (Fig. 2). Periglacial processes, which were in upland and plateau, changed morphometrical parameters of glacial accumulation forms, generated secondary relief forms and complicated upper layer of sediments - mostly created weathering and loess layers. The network of gullies is dense: the most density is in northern part of Medininkai Upland and amount to $15 \mathrm{~km} / \mathrm{km}^{2}$. Gullies modified sediments cover in mouth zones, which determined better infiltration of precipitation.

Later the processes essentially transformed sediments thickening. Very intense transformation was in areas, which covered by glaciofluvial, shallow glaciolacustrin and aeolian sediments.

A 5-7 m thick layer of sandy loam and clayey material covers the surface of the Medininkai Upland in which upper parts formed loess lens and streaks (Fig. 4), periglacial pockets (Fig. 5) and ice wedges (Fig. 6). In respect to their composition, colour, iron and carbonate content, and occurrence of cryogenic structures, the cover formations have been subdivided into 3 lithocomplexes, which different sediments composition and very various conditions of precipitation infiltration (Fig.7). 


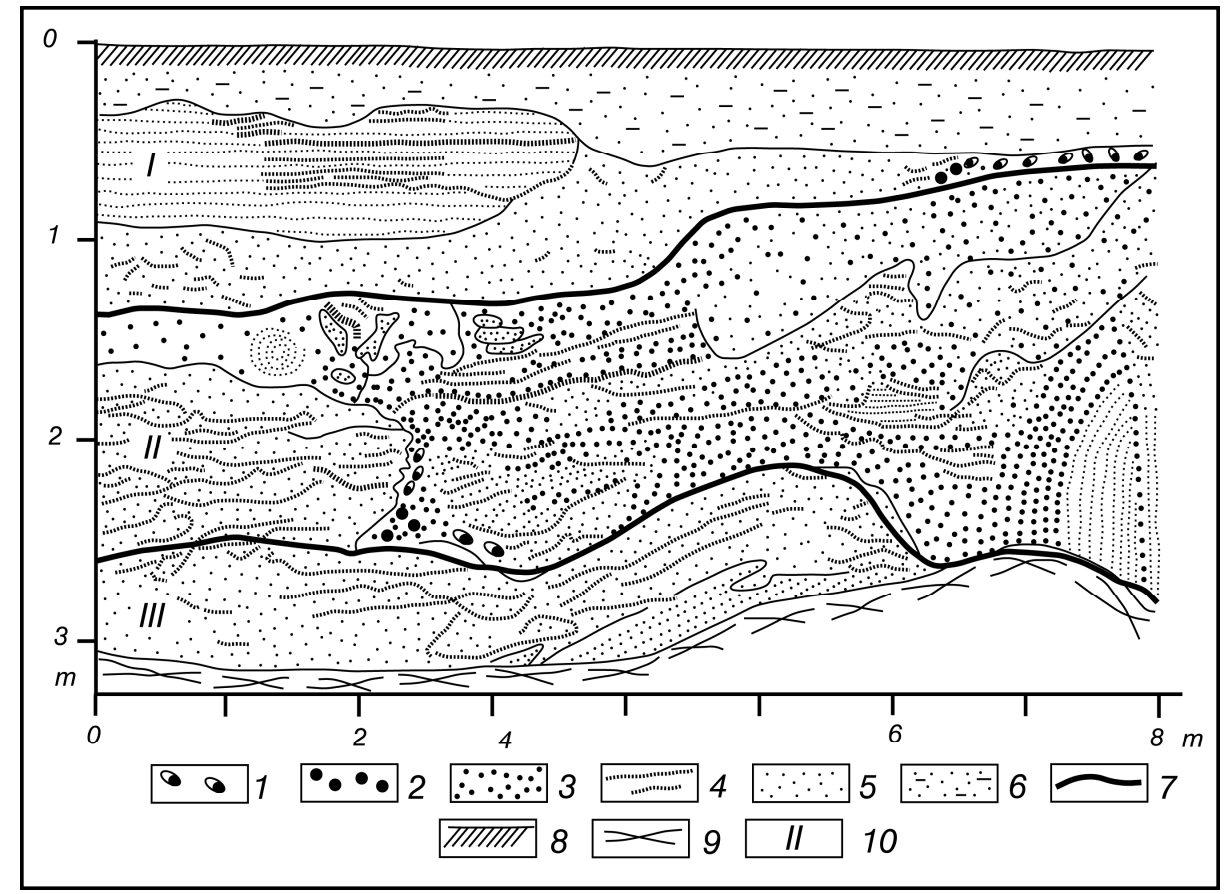

Fig. 4. Exposure of periglacial and loess formation in Eišiškès Plateau (south - east Lithuania): 1 - boulders; 2 - pebble; 3 - gravel; 4 - streaks of red iron oxides and carbonates; 5 - sand; 6 - fine-grained eolian sand; 7 - borderline of lithocomplexes; 8 - soil; 9 - landslip; 10 - number of lithocomplexes

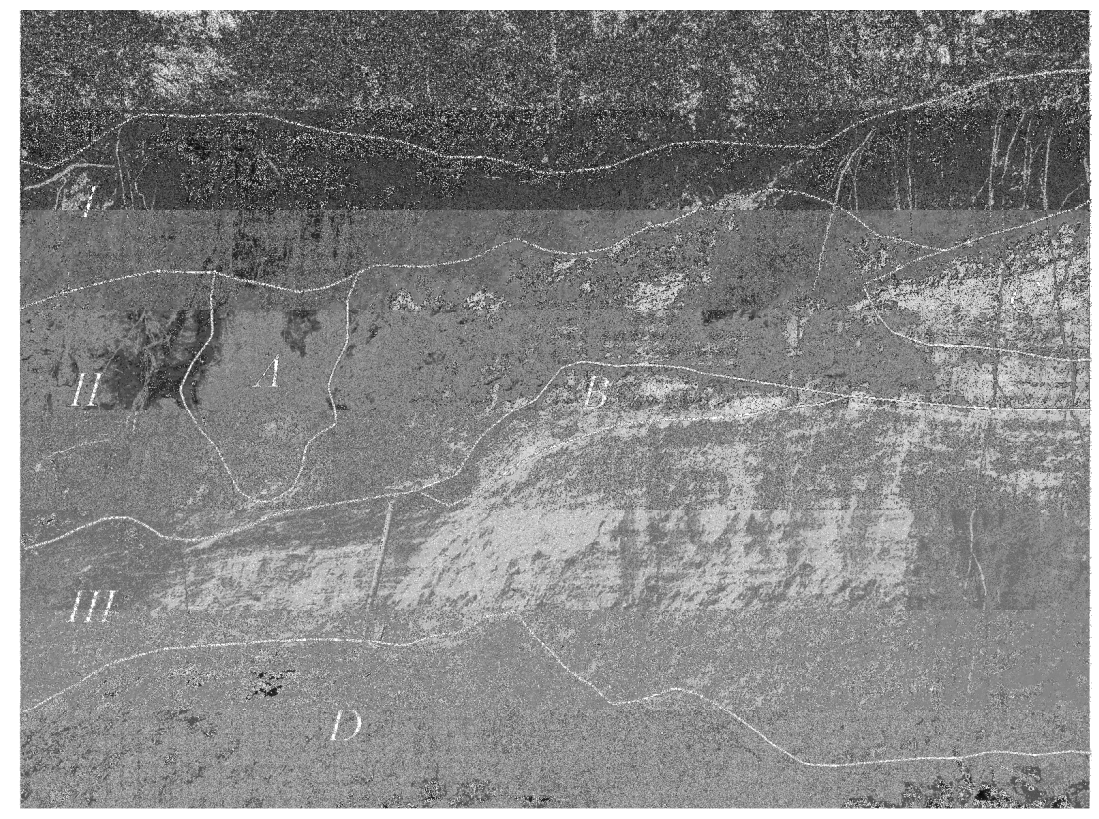

Fig. 5. Exposure of periglacial formation at countryside Montviliškis: I - III number of lithocomplexes; A - ice wedge; $\mathrm{B}$ - permafrost insertion; $\mathrm{C}$ - permafrost involution; D - colluvium 


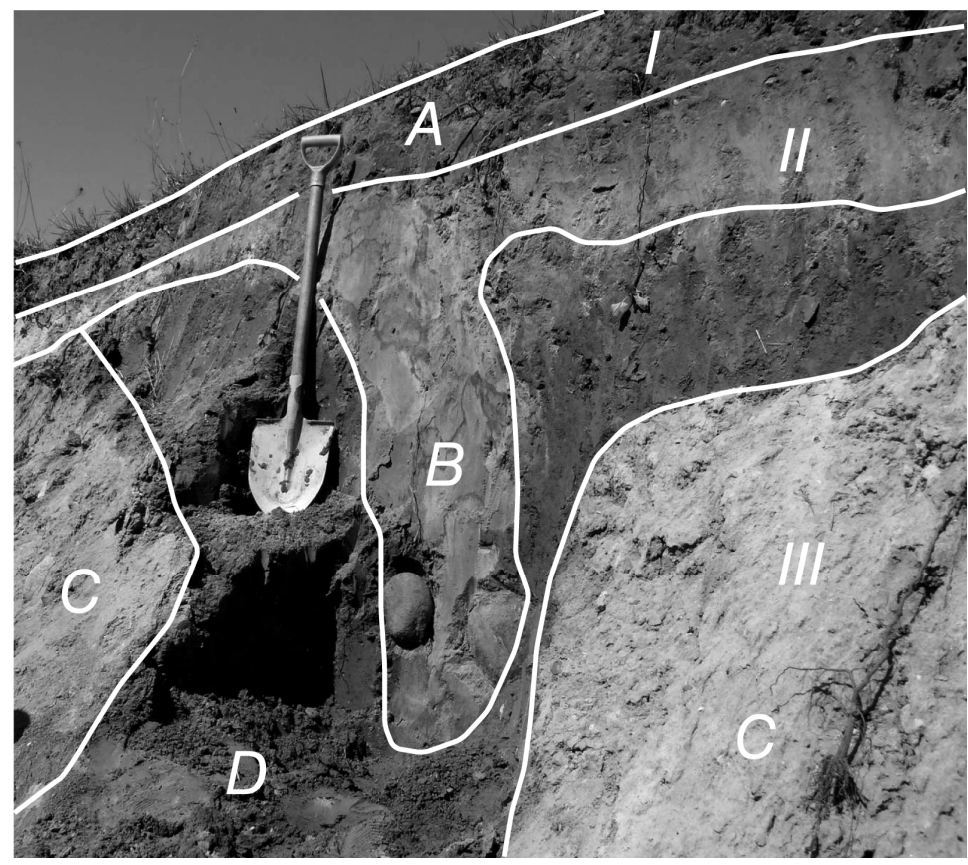

Fig. 6. Exposure of periglacial formation at countryside Stakai: I - III number of lithocomplexes; A - soil layer; B - ice wedge; $\mathrm{C}$ - glaciofluvial sand, D - moraine insertion

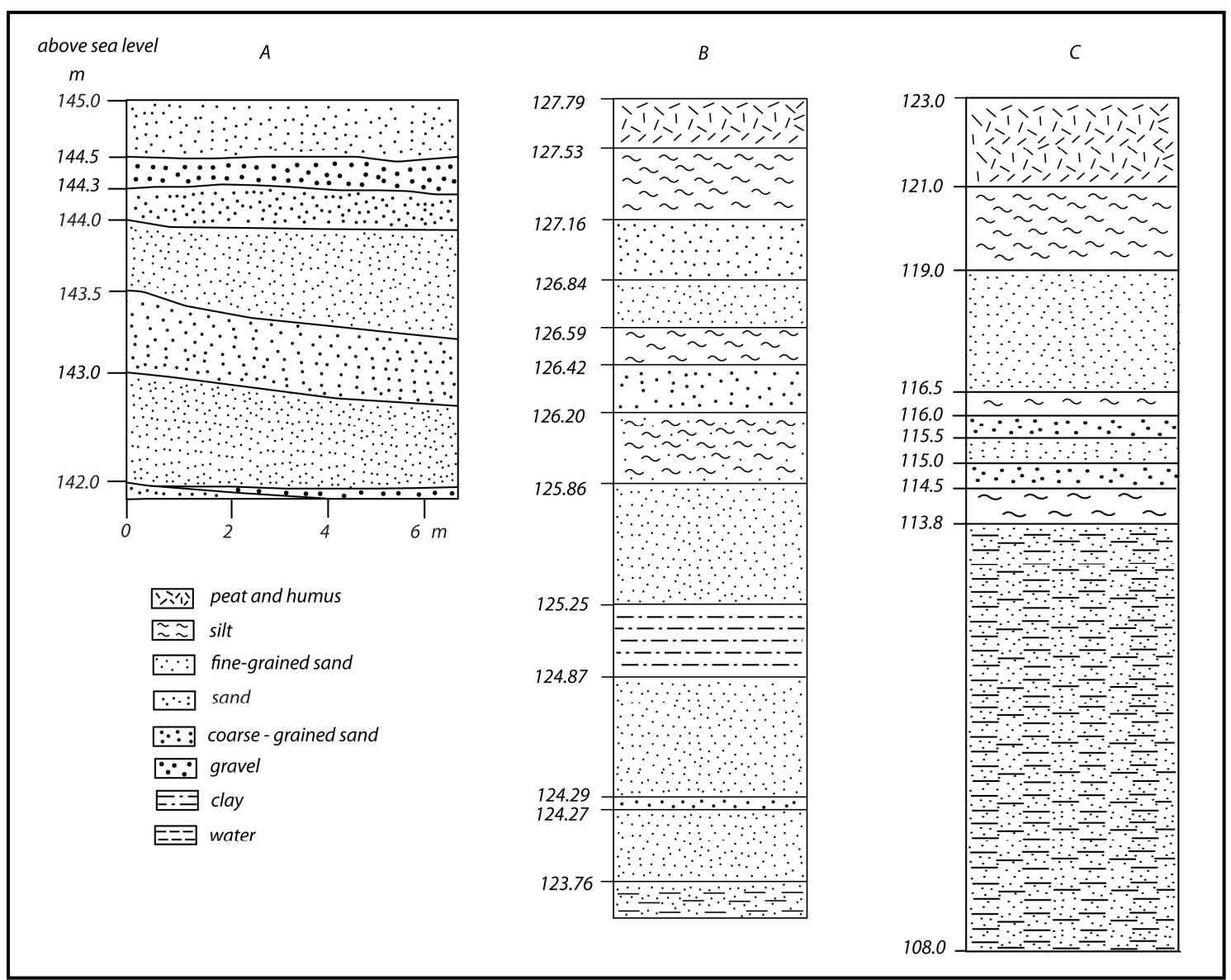

Fig. 7. Outcrops and boreholes of Merkys Middle- Stream (A); Ūla (B) and Biebrza (C) glaciolacustrine basins

In former shallow glaciolacustrine basins accumulated mostly sand and gravel (in shore-line and lithoral part), which determined good infiltration condition. In South Lithuania part (Merkys Middle-Stream, Katra and Biebrza basins) the bottom of former glaciolacustrine basin created wide areas for ground water accumulation. 
In former glaciolacustrine basins most of the times the sand and gravel have been gathering (in lithoral zone). Nowadays this fact results a good infiltration of precipitation. In Eastern and Southern Lithuania (Labanoras, Merkys Middle-Stream as well as Dubičiai and Biebrza basins) the bottom of previous glaciolacustrine basins became a good collector of precipitation waters. In these areas large groundwater resource have formed (Fig. 7). Precipitation waters infiltration modules reach up to 9-11 1/s km². However, in areas where previous catchments are swale, infiltration modules values are less $-3-51 / \mathrm{s} \mathrm{km}^{2}$.

Other Eastern Lithuania glaciolacustrine basins (Dysna, Pavoverè, and Ašmena) were deeper. In their bottoms was gathering clay and silt. As a result, precipitation infiltration conditions are much worse. Infiltration modules values in these areas reach only from 2 until $4 \mathrm{l} / \mathrm{s} \mathrm{km}^{2}$.

\section{Conclusion}

Eastern and Southern Lithuania glaciolacustrine basins are asynchronous formations. The oldest have formed 130000 years ago (Ašmena), younger of them - 17 000-19 000 years ago (Vilnia, Dysna, Dubičiai). The basins have formed evolving cascade that separate segments have been in different height. The highest segments reached $220 \mathrm{~m}$ (Ašmena basins) and the lowest $-110 \mathrm{~m}$.

In glaciolacustrine basins heterogeneous sediments have concentrated. They resulted precipitation water infiltration qualities and gathered groundwater amount. In deep basins clay and silt were covering as in shallow the various grain sand and gravel (littoral zones).

In deep glaciolacustrine basins formed sediments resulted low infiltration supply module: from 1-3 1/s $\mathrm{km}^{2}$ within Dysna and Ašmena basins up to $3-51 / \mathrm{s} \mathrm{km}^{2}$ Pavovere and Vilnia basins. In shallow glaciolacustrine basins rougher sediments resulted comparatively high value of the infiltration supply module. It reaches from $3-51 / \mathrm{s} \mathrm{km}^{2}$ in waterlogged Dubičiai, Labanoras, and Merkys-Middlestream as well as in parts of Biebrza up to $9-11 \mathrm{l} / \mathrm{s} \mathrm{km}^{2}$ in previous basins littoral zone.

\section{References}

[1] Česnulevičius, A.; Švedas, K. 2010. Paleogeography and evolution of the Dubičiai glaciolacustrine basin in southern Lithuania, Estonian Journal of Earth Sciences 59(4): 141-150. http://dx.doi.org/10.3176/earth.2010.2.04

[2] Seiriene,V.; Mazeika, J.; Petrosius, R.; Kabailiene, M.; Kasperoviciene, J.; Paskauskas, R. 2008. Lake sediments - a chronicle of natural and anthropogenic changes, Geological View 2: 29-34.

[3] Stancikaite, M.; Kabailiene, M.; Ostrauskas, T.; Guobyte, R. 2002. Environment and man around Lakes Duba and Pelesa, SE Lithuania, during the Late Glacial and Holocene, Geological Quarterly 46(4): 391-409.

[4] Česnulevičius, A. 2011. Method for evaluation water budget in small river catchments, in Proc. of the $8^{\text {th }}$ International Conference Environmental Engineering 2: 538-542. ISBN 978-9955-28-828-2. 